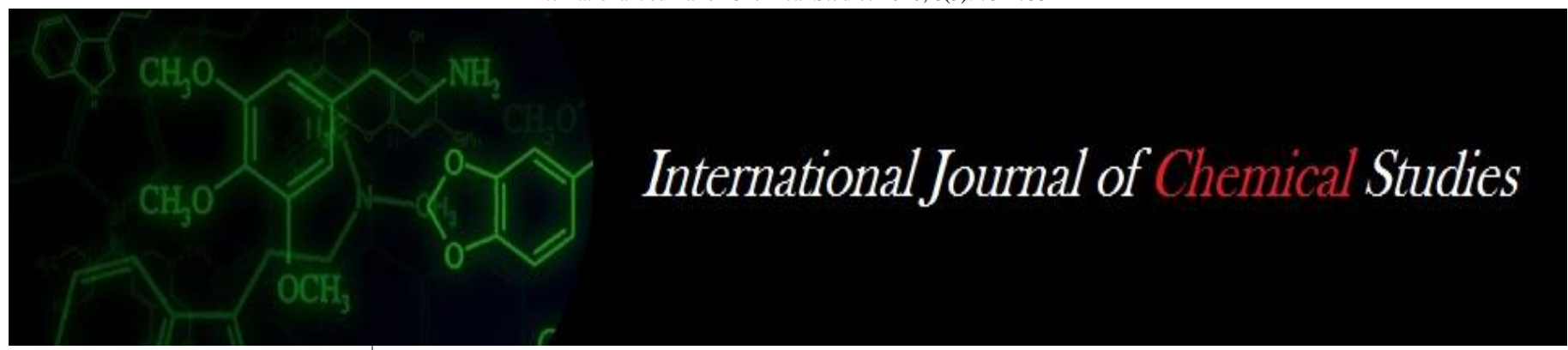

P-ISSN: 2349-8528

E-ISSN: 2321-4902

www.chemijournal.com

IJCS 2020; 8(3): 731-733

(C) 2020 IJCS

Received: 11-03-2020

Accepted: 13-04-2020

\section{Kanhaiya Lal}

Department of Genetics and

Plant Breeding, CS Azad

University of Agriculture and

Technology, Kanpur, Uttar

Pradesh, India

\section{Sarvendra Kumar}

Department of Genetics and

Plant Breeding, CS Azad

University of Agriculture and

Technology, Kanpur, Uttar

Pradesh, India

\section{HC Singh}

Department of Genetics and

Plant Breeding, CS Azad

University of Agriculture and

Technology, Kanpur, Uttar

Pradesh, India

\section{Mahak Singh}

Department of Genetics and

Plant Breeding, CS Azad

University of Agriculture and

Technology, Kanpur, Uttar

Pradesh, India

\section{SK Singh}

Department of Genetics and

Plant Breeding, CS Azad

University of Agriculture and

Technology, Kanpur, Uttar

Pradesh, India

Rishabh Kumar Singh Department of Seed Science and Technology, CS Azad University of Agriculture and Technology, Kanpur, Uttar Pradesh, India

\section{Corresponding Author:}

\section{Kanhaiya Lal}

Department of Genetics and Plant Breeding, CS Azad University of Agriculture and Technology, Kanpur, Uttar Pradesh, India

\section{Direct selection parameter estimates for yield and its contributing traits in maize (Zea mays $\mathrm{L}$.)}

\author{
Kanhaiya Lal, Sarvendra Kumar, HC Singh, Mahak Singh, SK Singh \\ and Rishabh Kumar Singh
}

DOI: https://doi.org/10.22271/chemi.2020.v8.i3i.9291

\begin{abstract}
Heritability and Genetic advance are the direct selection parameters. Information on such parameters has great importance in enhancing the selection efficiency. Therefore, in the present investigation 77 maize genotypes including $54 \mathrm{~F} 1 \mathrm{~s}, 18$ lines, 3 testers and 2 check varieties were evaluated in relation to direct selection parameters for different quantitative traits. All the genotypes showed significant variability for all the characters studied. High values $(>20 \%)$ of genotypic coefficient of variance (GCV) and phenotypic coefficient of variance (PCV) were recorded for the traits, grain yield per plant, kernels per cob, cob weight and kernels per row. The traits such as seed vigour index, seedling length, cob length, cobs per plant 100-kernel weight, plant height and kernel rows per cob showed moderate values (10$20 \%$ ) of GCV and PCV. For almost all the traits the values of GCV and PCV were almost similar but for cob diameter GCV was low while PCV was high indicated that all the traits had low environmental influence except cob diameter that had high environmental influence. High estimates of heritability coupled with high estimates of genetic advance as percent of mean were recorded for the traits grain yield per plant, kernels per cob, cob weight, kernels per row, seed vigour index, seedling length, 100kernel weight, cob length, plant height, cobs per plant and kernel rows per cob. This indicated the role of additive gene effect in the inheritance of these traits; therefore, such traits could be improved through simple selection.
\end{abstract}

Keywords: Direct selection parameters, heritability, genetic advance, quantitative traits and maize (Zea mays L.)

\section{Introduction}

Maize (Zea mays L.) is one of most important cereal crops, which ranks third after wheat and rice in the world. It's a versatile crop which provides food for humans, feed for animals particularly poultry and livestock. Population improvements of a crop is the primary objective of a plant-breeding program. However, the success of any breeding programme depends upon the existing variability in the population and the proportion of variability which has high transmissibility from parents to their offspring. Heritability is one of the most important direct selection parameters which determines whether the phenotypic differences observed among the various individuals are due to differences in their genetic make-up or simply the result of environmental factors. Robinson et al., $1949^{[17]}$ emphasized the importance of heritability in efficient selection strategy. Taking above pints under consideration the present investigation was carried out to find out the estimates of direct selection parameters for yield and its contributing traits.

\section{Materials and Methods}

The experimental material for this study consists of $54 \mathrm{~F} 1 \mathrm{~s}$ (obtained through the crossing of 18 lines (females) with 3 testers (males) in line x tester design during Kharif 2018), 18 lines (females), 3 testers (males) and 2 check varieties. All the seventy-seven treatments were evaluated at Student Instructional Farm CS Azad University of Agriculture and Technology, Kanpur-208002 (U.P.), India during Rabi 2018-19 in Randomized complete block design (RCBD) in one row plots of $4 \mathrm{~m}$ length with $60 \times 25 \mathrm{~cm}$ spacing and replicated three times. Observations on plant height, number of cobs/plant, number of kernel rows/cob, number of kernels/row, cob length $(\mathrm{cm})$, cob diameter $(\mathrm{cm})$, cob weight $(\mathrm{g})$, number of kernels/cob, 
100-kernel weight (g), grain yield/plant (g) and shelling percentage $(\%)$ were recorded on 5 randomly selected plants per entry per replication while, data on days to $50 \%$ tasselling, days to $50 \%$ silking, days to $75 \%$ dry husk, were recorded on plot basis. Data on germination percentage (\%), seedling length $(\mathrm{cm})$ and seed vigour index were recorded by following standard seed laboratory protocols. All the recommended cultural practices were followed to raise a good crop. The mean values of recorded data were used for Analysis of variance for Randomized Complete Block Design (Panse and Sukhatme, 1985) ${ }^{[15]}$, Phenotypic, genotypic, and environmental coefficients of variation for different characters (Burton and de Vane, 1953) ${ }^{[4]}$, heritability in broad sense $\left(\mathrm{h}^{2} \mathrm{~b}\right)$ (Hanson, 1963) ${ }^{[6]}$, the expected genetic advance (Ga) and genetic advance as percent of mean (Johnson et al., 1955) [9].

\section{Result and Discussion}

The first requirement of any breeding programme is variability because if there are no variability in the population there will be no chance of selection. However, efficiency of selection depends on such variability which is highly transmissible from parents to their offspring. Thus, finding of heritability estimates for yield and its component traits is much more important. The estimates of heritability alone are unable to provide information regarding to genetic progress in various characters. The estimates of heritability along with genetic advance provide more reliable information regarding to such aspects. It is therefore, necessary to utilize heritability estimates in conjunction with genetic advance which would then indicate the expected genetic gain from the selection.

Analysis of variance for yield and its component traits was done and presented in table 1. All the genotypes showed significant variability for all the characters studied. Significant difference among the genotypes for studied characters have also been reported by Mhoswa et al. (2016) [11], Thakur et al. (2016) [21], Shengu (2017) ${ }^{[19]}$, Bisen et al. (2018) [3], Beulah et al. (2018) ${ }^{[2]}$, Bartaula et al. (2019) ${ }^{[1]}$, Prakash et al. (2019) ${ }^{[16]}$, Ubi et al. (2019) ${ }^{[22]}$, Devi (2020) ${ }^{[5]}$, Islam et al. (2020) [8] and Taiwo et al. (2020) ${ }^{[20]}$. The estimates of genotype coefficient of variance (GCV) and phenotypic coefficient of variance (PCV) are presented in table 2. High values (>20\%) of GCV and PCV were recorded for grain yield per plant, kernels per cob, cob weight and kernels per row. Prakash et al., $2019^{[16]}$ has also reported High PCV and GCV for the same characters. Maruthi and Rani, $2015^{[10]}$ has reported high GCV and PCV for grain yield per plant and kernels per row. High value of GCV and PCV for cob weight has also reported by Ogunniyan and Olakojo, $2015^{[13]}$. The traits such as seed vigour index, seedling length, cob length, cobs per plant 100-kernel weight, plant height and kernel rows per cob showed moderate values (10-20\%) of GCV and PCV. Sandeep et al., $2015^{[18]}$ has also reported moderate values of GCV and PCV for cob length, 100 -kernel weight and plant height. Low values of GCV and PCV $(<10 \%)$ were recorded for days to $50 \%$ tasseling, days to $50 \%$ silking, days to $75 \%$ dry husk, shelling (\%) and germination (\%). Pandey et al., $2017^{[14]}$ has also reported low estimates of GCV and PCV for days to $50 \%$ tasseling, days to $50 \%$ silking, days to $75 \%$ dry husk, shelling (\%).

The estimates of heritability and genetic advance are presented in table 2. High estimates of heritability $(>61 \%)$ were showed by almost all the traits except germination percentage and cob diameter which showed moderate estimates of heritability (31-60\%). Ogunniyan and Olakojo, $2015^{[13]}$, Mohammad et al. (2017) ${ }^{[12]}$, Maruti and Rani 2015 ${ }^{[10]}$, Islam et al., $2020{ }^{[8]}$ have also reported high heritability for all the traits studied by them. High estimates of genetic advance as percent of mean $(>20 \%)$ were reported for grain yield per plant, kernels per cob, cob weight, kernels per row, seed vigour index, seedling length, 100-kernel weight, cob length, plant height, cobs per plant, kernel rows per cob. High estimates of heritability coupled with high estimates of genetic advance as percent of mean were reported for grain yield per plant, kernels per cob, cob weight, kernels per row, seed vigour index, seedling length, 100-kernel weight, cob length, plant height, cobs per plant and kernel rows per cob. The findings of this study are in broadly agreement with the findings of Maruthi and Rani (2015) ${ }^{[10]}$, Sandeep et al (2015) [18], Thakur et al. (2016) ${ }^{[21]}$, Prakash et al. (2019) ${ }^{[16]}$, Hussain et al. (2019) [7], Ubi et al. (2019) ${ }^{[22]}$, Devi (2020) ${ }^{[5]}$, and Islam et al. (2020) ${ }^{[8]}$. The characters that showed high heritability coupled with high genetic advance could be improved through simple selection.

Table 1: Analysis of variance for yield and its component traits in maize

\begin{tabular}{|c|c|c|c|c|c|c|c|c|c|c|}
\hline $\begin{array}{c}\text { Source of } \\
\text { variation }\end{array}$ & d.f. & $\begin{array}{c}\text { Days to 50\% } \\
\text { tasseling }\end{array}$ & $\begin{array}{c}\text { Days to } \\
\mathbf{5 0 \%} \text { silking }\end{array}$ & $\begin{array}{c}\text { Days to 75\% } \\
\text { dry husk }\end{array}$ & $\begin{array}{c}\text { Plant height } \\
\text { (cm) }\end{array}$ & $\begin{array}{c}\text { Number of } \\
\text { cobs/plant }\end{array}$ & $\begin{array}{c}\text { Cob } \\
\text { length } \\
\text { (cm) }\end{array}$ & $\begin{array}{c}\text { Cob diameter } \\
\text { (cm) }\end{array}$ & $\begin{array}{c}\text { Cob } \\
\text { weight } \\
\text { (g) }\end{array}$ & $\begin{array}{c}\text { Number of } \\
\text { kernel rows/cob }\end{array}$ \\
\hline Replication & 2 & 2.09 & 1.09 & 3.65 & 3.43 & 0.030 & 0.84 & 0.92 & 2.09 & 1.09 \\
\hline Treatment & 76 & $22.11^{* *}$ & $23.80^{* *}$ & $27.55^{* *}$ & $1319.21^{* *}$ & $0.095^{* *}$ & $15.02^{* *}$ & $2.55^{* *}$ & $22.11^{* *}$ & $23.80^{* *}$ \\
\hline Error & 152 & 1.55 & 1.63 & 4.53 & 48.93 & 0.013 & 1.04 & 0.93 & 1.55 & 1.63 \\
\hline
\end{tabular}

\begin{tabular}{|c|c|c|c|c|c|c|c|c|c|}
\hline $\begin{array}{c}\text { Source of } \\
\text { variation }\end{array}$ & d.f. & $\begin{array}{c}\text { Number of } \\
\text { kernels / row }\end{array}$ & $\begin{array}{c}\text { Number of } \\
\text { kernels /cob }\end{array}$ & $\begin{array}{c}\text { 100-Kernel } \\
\text { weight (g) }\end{array}$ & $\begin{array}{c}\text { Shelling } \\
\text { percentage (\%) }\end{array}$ & $\begin{array}{c}\text { Grain } \\
\text { yield/plant (g) }\end{array}$ & $\begin{array}{c}\text { Germination } \\
\text { percentage (\%) }\end{array}$ & $\begin{array}{c}\text { Seedling } \\
\text { length (cm) }\end{array}$ & $\begin{array}{c}\text { Seed vigour } \\
\text { index }\end{array}$ \\
\hline Replication & 2 & 1.44 & 0.11 & 0.10 & 9.04 & 0.02 & 1.62 & 0.40 & -0.08 \\
\hline Treatment & 76 & $2219.28^{* *}$ & $5.51^{* *}$ & $96.20^{* *}$ & $23783.10^{* *}$ & $34.17^{* *}$ & $160.79 * *$ & $2481.90^{* * *}$ & $30.52^{* *}$ \\
\hline Error & 152 & 2.02 & 0.03 & 0.06 & 7.75 & 0.05 & 2.20 & 15.87 & 12.98 \\
\hline
\end{tabular}

*,** significant at $5 \%$ and $1 \%$ level, respectively

Table 2: Estimates of GCV, PCV, heritability and genetic advance for yield and its component traits in maize

\begin{tabular}{|c|c|c|c|c|c|c|c|c|}
\hline Genotypes & Mean & Min & Max & Heritability (\%) & Ga & Ga as \% mean & GCV (\%) & PCV (\%) \\
\hline Days to 50\% tasseling & 123.34 & 117.33 & 130.33 & 81.50 & 4.87 & 3.95 & 2.12 & 2.35 \\
\hline Days to 50\% silking & 127.11 & 121.22 & 133.33 & 81.89 & 5.07 & 3.99 & 2.14 & 2.36 \\
\hline Days to 75\% dry husk & 164.85 & 157.00 & 168.67 & 62.80 & 4.52 & 2.74 & 1.68 & 2.12 \\
\hline Plant height (cm) & 172.87 & 114.00 & 215.82 & 89.64 & 40.14 & 23.22 & 11.90 & 12.57 \\
\hline
\end{tabular}




\begin{tabular}{|c|c|c|c|c|c|c|c|c|}
\hline Number of cobs/plant & 1.21 & 1.00 & 1.90 & 67.07 & 0.28 & 23.09 & 13.68 & 16.71 \\
\hline Cob length $(\mathrm{cm})$ & 15.62 & 10.35 & 20.93 & 81.70 & 4.02 & 25.72 & 13.81 & 15.28 \\
\hline Cob diameter (cm) & 11.71 & 9.37 & 13.91 & 36.57 & 0.91 & 7.80 & 6.26 & 10.35 \\
\hline Cob weight $(\mathrm{g})$ & 96.99 & 42.95 & 156.41 & 99.73 & 55.93 & 57.66 & 28.03 & 28.07 \\
\hline No of kernel rows/cob & 13.08 & 10.06 & 15.33 & 98.33 & 2.76 & 21.12 & 10.34 & 10.43 \\
\hline No of kernels / row & 22.92 & 10.13 & 34.46 & 99.82 & 11.65 & 50.84 & 24.70 & 24.72 \\
\hline No of kernels /cob & 302.06 & 104.50 & 483.74 & 99.90 & 183.30 & 60.68 & 29.47 & 29.49 \\
\hline 100-Kernel weight (g) & 25.24 & 14.65 & 32.44 & 99.54 & 6.93 & 27.46 & 13.36 & 13.39 \\
\hline Shelling (\%) & 77.73 & 55.38 & 88.77 & 96.00 & 14.68 & 18.88 & 9.35 & 9.55 \\
\hline Grain yield/plant (g) & 90.46 & 27.98 & 164.39 & 98.11 & 58.50 & 64.67 & 31.70 & 32.00 \\
\hline Germination (\%) & 91.23 & 84.67 & 97.67 & 31.06 & 2.78 & 3.04 & 2.65 & 4.76 \\
\hline Seedling length (cm) & 27.60 & 17.28 & 37.90 & 94.62 & 9.49 & 34.39 & 17.16 & 17.64 \\
\hline Seed vigour index & 2522.45 & 1460.35 & 3522.30 & 95.03 & 926.74 & 36.74 & 18.30 & 18.77 \\
\hline
\end{tabular}

\section{References}

1. Bartaula S, Panthi U, Timilsena K, Acharya SS, Shrestha J. Variability, heritability and genetic advance of maize (Zea mays L.) Genotypes. Res. Agric. Livest. Fish. 2019; 6(2):163-169.

2. Beulah G, Marker S, Rajasekhar D. Assessment of quantitative genetic variability and character association in maize (Zea mays L.). Journal of Pharmacognosy and Phytochemistry. 2018; 7(1):2813-2816.

3. Bisen N, Rahangdale CP, Sahu RP. Genetic Variability and correlation studies of yield and yield component in maize hybrids (Zea mays L.) under kymore plateau and satpura hill region of Madhya Pradesh. International Journal of Agriculture, Environment and Biotechnology. 2018; 11(1):71-77.

4. Burton GM, de Vane EH. Estimating heritability in tall fescue (Festuca arundinacea) from replicated clonal material. Agron. J. 1953; 45:471-481.

5. Devi B. Appraisal of Genetic Variability for different quantitative traits in maize (Zea mays L.) genotypes. International Journal of Agriculture Sciences. 2020; 12(2): 9445-9447.

6. Hanson WD. Heritability in: WD Hanson and HF Robinson (Eds.) Statistical Genetics and Plant Breeding Publ. 982, Washington, DC National Academy of Science, National Research Council, 1963, 125-139.

7. Hussain MA, Askandar HS, Khether AA, Saaed RI. Evaluation of maize genotypes for yield and yield components and constructing selection index. Tikrit Journal for Agricultural Sciences. 2019; 19(4):76-82.

8. Islam NU, Ali G, Dar ZA, Maqbool S, Baghel S, Bhat A. Genetic variability studies involving drought tolerance related traits in maize (Zea mays L.) in breds. International Journal of Chemical Studies. 2020; $8(1): 414-419$.

9. Johnson HW, Robinson HF, Comstock RE. Genotypic and phenotypic correlation in soybean and their implication in selection. Agron. 1955; 47:477-483.

10. Maruthi RT, Rani KJ. Genetic variability, heritability and genetic advance estimates in maize (Zea mays L.) inbred lines. Journal of Applied and Natural Science. 2015; 7(1):149-154.

11. Mhoswa L, Derera J, Quabe FNP, Musimwa TR. Diversity and path coefficient analysis of Southern African maize hybrids. Chilean Journal of Agricultural Research. 2016; 76(2):143-15.

12. Mohammad QIM, Mohammad SU, Mohammad MR, Mohammad Azad AAK, Banik BR. Genetic variability and path analysis studies in hybrid maize (Zea mays L.). American Journal of Plant Sciences. 2017; 8:3101-3109.

13. Ogunniyan DJ, Olakojo SA. Genetic variation, heritability, genetic advance and agronomic character association of yellow elite inbred lines of maize (Zea mays L.). Nigerian Journal of Genetics. 2015; 28(2014):24-28.

14. Pandey Y, Vyas RP, Kumar J, Singh L, Singh HC, Yadav PC et al. Heritability, correlation and path coefficient analysis for determining interrelationships among grain yield and related characters in maize (Zea mays L.). Int. J Pure App. Biosci. 2017; 5(2):595-603.

15. Panse VG, Sukhatme PV. Statistical Methods for Agricultural Workers. $4^{\text {th }}$ Ed. ICAR, New Delhi, 1985, 361.

16. Prakash R, Ravikesavan R, Vinodhana N, Kumari SA. Genetic variability, character association and path analysis for yield and yield component traits in maize (Zea mays L.) Electronic Journal of Plant Breeding. 2019; 10(2):518-524.

17. Robinson HF, Comstock RE, Harvey PH. Estimates to heritability and degree of dominance in corn. Agron. J. 1949; 41:353-359.

18. Sandeep S, Bharathi M, Narsimha Reddy V, Eswari KB. Genetic variability, heritability and genetic advance studies in inbreds of maize (Zea mays L.). Eco. Env. \& Cons. 2015; 21:S445-S449.

19. Shengu MK. Genetic Study of Some Maize (Zea Mays L.) Genotypes in Humid Tropic of Ethiopia. International Journal of Scientific and Research Publications. 2017; 7(1):281-287.

20. Taiwo OP, Nwonuala AI, Isaiah BF. Variability in yield and yield components of selected pro-vitamin a maize (Zea mays L.) varieties in a humid environment of Port Harcourt, Nigeria. Asian Journal of Agricultural and Horticultural Research. 2020; 5(3):1-10.

21. Thakur S, Sinha SK, Mehta N, Thakur D. Genetic analysis of yield and its components in maize (Zea mays L.) inbred lines using line $x$ tester analysis. International Journal of Agriculture Sciences. 2016; 8(53):2768-2773.

22. Ubi GM, Onabe MB, Kalu SE. Path coefficient analysis, character association and variability studies in selected maize (Zea mays L.) genotypes grown in Southern Nigeria. Annual Research \& Review in Biology. 2019; 33(3):1-6. 